University of Nebraska - Lincoln

DigitalCommons@University of Nebraska - Lincoln

Faculty Publications: Department of Entomology

August 2000

\title{
Baseline Susceptibility of the Corn Earworm (Lepidoptera: Noctuidae) to the Cry1Ab Toxin from Bacillus thuringiensis
}

\author{
Blair D. Siegfried \\ University of Nebraska-Lincoln, bsiegfried1@ufl.edu \\ Terrence A. Spencer \\ University of Nebraska-Lincoln, tspencer1@unl.edu \\ Jessica Nearman \\ University of Nebraska-Lincoln
}

Follow this and additional works at: https://digitalcommons.unl.edu/entomologyfacpub

Part of the Entomology Commons

Siegfried, Blair D.; Spencer, Terrence A.; and Nearman, Jessica, "Baseline Susceptibility of the Corn Earworm (Lepidoptera: Noctuidae) to the Cry1Ab Toxin from Bacillus thuringiensis" (2000). Faculty Publications: Department of Entomology. 34.

https://digitalcommons.unl.edu/entomologyfacpub/34

This Article is brought to you for free and open access by the Entomology, Department of at DigitalCommons@University of Nebraska - Lincoln. It has been accepted for inclusion in Faculty Publications: Department of Entomology by an authorized administrator of DigitalCommons@University of Nebraska - Lincoln. 


\section{Baseline Susceptibility of the Corn Earworm (Lepidoptera: Noctuidae) to the Cryl Ab Toxin from Bacillus thuringiensis}

Blair D. Siegfried, Terrence Spencer, and Jessica Nearman

Journal of Economic Entomology

Volume 93, Issue 4 (August 2000) pp. 1265-1268

DOI: 10.1603/0022-0493(2000)093[1265:BSOTCE]2.0.CO;2

Authors may post electronic reprints of their own journal articles after an embargo period of two years has passed from the date of publication. Also, authors must include on the electronic reprint the following statement:

This article is the copyright property of the Entomological Society of America and may not be used for any commercial or other private purpose without specific written permission of the Entomological Society of America. 


\title{
Baseline Susceptibility of the Corn Earworm (Lepidoptera: Noctuidae) to the CrylAb Toxin from Bacillus thuringiensis
}

\author{
BLAIR D. SIEGFRIED, TERRENCE SPENCER, AND JESSICA NEARMAN
}

Department of Entomology, 202 Plant Industry Building, University of Nebraska, Lincoln, NE 68583-0816

\begin{abstract}
J. Econ. Entomol. 93(4): 1265-1268 (2000)
ABSTRACT Susceptibility to CrylAb toxin from Bacillus thuringiensis (Bt) was determined for 12 field populations of neonate corn earworm, Helicoverpa zea (Boddie), from the United States. Earworm larvae were exposed to artificial diet treated with increasing Bt concentrations, and mortality and growth inhibition were evaluated after $7 \mathrm{~d}$. The range of variation in Bt susceptibility indicated by growth inhibition was very similar to that indicated by mortality. Although interpopulation variation in susceptibility to both proteins was observed, the magnitude of the differences was small (less than or equal to fivefold). These results suggest that the observed susceptibility differences reflect natural variation in Bt susceptibility among corn earworm populations rather than variation caused by prior exposure to selection pressures. Therefore, corn earworms apparently are susceptible to $\mathrm{Bt}$ toxins across most of their geographic range.
\end{abstract}

KEY WORDS Baccilus thuringiensis susceptibility, geographic variability, bioassay

INCREASING PUBLIC CONCERNS about environmental hazards and widespread resistance in pest populations are threatening the continued effectiveness of conventional insecticides and should increase the use of insecticidal products derived from Bacillus thuringiensis Berliner in the next decade (Tabashnik 1994). This is particularly true for transgenic Bt crops, which represent an important new tool for pest management (Fischhoff 1996). However, increased use of B. thuringiensis in agriculture via transgenic plants and other modes of application likely will increase the intensity of selection for Bt resistance in pest populations.

The possibility of resistance highlights the need to develop and implement resistance management strategies to prevent or delay the evolution of resistance to B. thuringiensis toxins (Hokkanen and Wearing 1994). These strategies are dependent on the development of effective resistance monitoring programs capable of early detection of resistance that will allow implementation of appropriate management decisions in a timely manner (Dennehey 1987). The initial steps in implementing such programs include development of appropriate bioassay techniques and establishment of baseline susceptibility data among populations across the geographic range of the target species. With this information, potential population susceptibility changes in response to selection with $B$. thuringiensis can be identified (Fischhoff 1996).

The corn earworm, Helicoverpa zea (Boddie), is a serious pest of maize, Zea mays L., in the United States (Mason et al. 1996) and a major target pest for control with transgenic Bt corn (Fischhoff 1996). This pest causes primary damage to corn plants by feeding on ears, although whorl feeding does occur in early generations (Neunzig 1969, Keith and Witkowski 1996).
The insect is a generalist feeder on both weed and crop plants, including cotton, tobacco, and tomato (Metcalf and Metcalf 1993).

Corn earworms are unable to overwinter in the northern United States. However, in southern states, where populations are potentially exposed to both transgenic cotton and corn in alternate generations, there is a high level of concern regarding the increased potential for selection pressure and resistance development (International Life Sciences Institute 1998). This is especially true because of the shared binding site between the CrylAb and CrylAc toxins that are expressed in Bt corn and cotton (Tabashnik 1994, Gould 1998), respectively. Furthermore, the expression level in either crop plant is probably insufficient to achieve a high dose for this pest species because of generally higher tolerance to the Bt toxins (International Life Sciences Institute 1998).

Variation in susceptibility to the CrylAc has been documented previously among geographically distinct H. zea populations (Stone and Sims 1993, Sims et al. 1996) and annual evaluations of susceptibility to CrylAc are conducted for insects collected from cotton. The objective of the current study was to establish a baseline of susceptibility to CrylAb toxins from geographically distinct populations of $H$. zea collected from corn, emphasizing areas where there is likely to be exposure to both transgenic corn and cotton.

\section{Materials and Methods}

Insects. Populations of corn earworm were collected from nine states from both northern and southern areas of the corn belt and bioassayed to determine susceptibility to the CrylAb Bt endotoxin (Table 1). 
Table 1. Source description of European corn borer populations used to establish baseline susceptibility to the CrylAb toxin from B. thuringiensis

\begin{tabular}{lccr}
\hline \hline \multicolumn{1}{c}{ Collection site } & $\begin{array}{c}\text { Parental } \\
\text { Population }\end{array}$ & $\begin{array}{c}\text { Generation } \\
\text { Bioassayed }\end{array}$ & $\begin{array}{c}\text { Sample } \\
\text { size }\end{array}$ \\
\hline Loxley, AL & 200 & $\mathrm{~F}_{1}$ & 784 \\
Salisbury, MD & 199 & $\mathrm{~F}_{2}$ & 748 \\
Upper Marlboro, MD & 152 & $\mathrm{~F}_{2}$ & 1,120 \\
Fayetteville, AK & 150 & $\mathrm{~F}_{1}-\mathrm{F}_{2}$ & 896 \\
Aurora, NE & 236 & $\mathrm{~F}_{1}$ & 784 \\
Plymouth, NC & $>100$ & $\mathrm{~F}_{1}$ & 672 \\
Leland, MS & 117 & $\mathrm{~F}_{1}-\mathrm{F}_{2}$ & 672 \\
Stoneville, MS & 196 & $\mathrm{~F}_{2}$ & 672 \\
Loxley, AL & 200 & $\mathrm{~F}_{1}-\mathrm{F}_{3}$ & 1,120 \\
Washington County, MS (Bt) & 175 & $\mathrm{~F}_{1}-\mathrm{F}_{2}$ & 748 \\
Washington County, MS & $>200$ & $\mathrm{~F}_{1}-\mathrm{F}_{3}$ & 896 \\
Rosemont, MN & $>100$ & $\mathrm{~F}_{1}$ & 896 \\
Laboratory Colony $^{a}$ & - & $\mathrm{F}_{5}$ & 672 \\
\hline
\end{tabular}

${ }^{a}$ Colony initiated in 1997 from Stratford, TX, field collection.

Populations were obtained by Novartis personnel as late instars from both field corn and sweet corn and sent to the University of Nebraska. Additional collections were obtained as larvae or pupae from corn plants by the Monsanto Company and provided to Agripest Crop Consulting, Zebulon, NC, for rearing. Field-collected insects were reared to adults and allowed to mate using standardized rearing techniques (Stone and Sims 1991). Eggs from the mated females were collected and allowed to hatch. Neonate larvae obtained from the field-collected parents were used for subsequent bioassays or used to initiate another generation if insufficient numbers were available for bioassay. A laboratory colony initiated from a 1997 field collection was also bioassayed.

Corn Earworm Bioassays. Bioassay of corn earworm neonates involved exposure to Bt solutions applied to the surface of single wells of artificial diet (Marçon et al. 1999). Bioassays were performed in 128 -well trays (each well $16 \mathrm{~mm}$ diameter by $16 \mathrm{~mm}$ high; CD International, Pitman, NJ). Dilutions of B. thuringiensis were prepared in $0.1 \%$ Triton-X 100 to obtain uniform spreading of $\mathrm{Bt}$ solution on the diet surface. The pro- tein used for bioassays consisted of purified CrylAb obtained from the B. thuringiensis kurstaki strain HD1-9, which produces only CrylAb protein (provided by the Novartis, Research Triangle Park, NC). The crystal protein preparation was obtained by density gradient centrifugation and contains $\approx 98 \%$ crystal protein as determined by phase contrast microscopy. Individual neonate larvae ( $<24 \mathrm{~h}$ after hatching) were placed in wells, and mortality and individual larval weight recorded $7 \mathrm{~d}$ later. Control treatments consisted of wells treated with $0.1 \%$ Triton-X 100 . When mortality was recorded, larvae that had not grown beyond first instar and weighed $\leq 10 \mathrm{mg}$ were considered to be dead. As a result, the criterion for mortality used in this study accounts for both severe growth inhibition and death.

Statistical Analyses. Bioassays were conducted in duplicate on three different dates and included at least five $\mathrm{Bt}$ concentrations that produced significant growth inhibition and mortality as defined previously. Because of difficulties in obtaining enough larvae from a single generation, results from multiple generations were combined for some populations. Individual larval weights were recorded after 7-d exposures and transformed to percentage of growth inhibition relative to the controls, and these data were analyzed by nonlinear regression (SAS Institute 1988, Marçon et al. 1999). Mortality data were analyzed by probit analysis (Finney 1971) using POLO-PC (LeOra Software 1987).

\section{Results and Discussion}

Susceptibility data for $H$. zea populations exposed to purified CrylAb protein are presented in Table 2. $\mathrm{LC}_{50}$ values ranged from $70.3 \mathrm{ng} / \mathrm{cm}^{2}$ (laboratory colony) to $221.3 \mathrm{ng} / \mathrm{cm}^{2}$ (Plymouth, NC). $\mathrm{EC}_{50}$ values (i.e., concentrations that caused $50 \%$ growth inhibition of corn earworm larvae) ranged from $2.67 \mathrm{ng} / \mathrm{cm}^{2}$ (Marlboro, MD) to $13.31 \mathrm{ng} / \mathrm{cm}^{2}$ (Plymouth, NC). Differences between the most susceptible and most tolerant populations were three- and fivefold at the

Table 2. Susceptibility of corn earworm neonates exposed to the CrylAb protein from B. thuringiensis as measured by growth inhibition and mortality

\begin{tabular}{|c|c|c|c|c|c|c|}
\hline Populations & $\mathrm{EC}_{50}(95 \% \mathrm{CI})^{a, b}$ & Slope $\pm \mathrm{SE}$ & $\mathrm{LC}_{50}(95 \% \mathrm{CI})^{b}$ & $\mathrm{LC}_{90}(95 \% \mathrm{CI})^{b}$ & $\chi^{2}$ & $\mathrm{df}$ \\
\hline Nebraska & $8.72(6.20-12.3)$ & $3.29 \pm 0.43$ & $157.0(137.2-177.8)$ & $384.2(321.5-494.9)$ & 1.90 & 5 \\
\hline Garden City, KS & $6.95(5.37-8.89)$ & $2.45 \pm 0.22$ & $131.6(110.1-155.8)$ & $444.3(535.9-599.0)$ & 2.73 & 5 \\
\hline Leland, MS & $5.47(3.63-8.08)$ & $2.70 \pm 0.31$ & $201.3(153.9-250.5)$ & $599.9(442.3-1050.1)$ & 7.11 & 5 \\
\hline Upper Marlboro, MD & $5.83(4.95-6.82)$ & $2.63 \pm 0.21$ & $149.5(130.7-169.1)$ & $389.3(389.3-568.2)$ & 2.29 & 5 \\
\hline Salisbury, MD & $4.93(3.55-6.55)$ & $2.04 \pm 0.23$ & $121.1(72.6-173.9)$ & $512.4(333.3-1137.9)$ & $9.03^{c}$ & 5 \\
\hline Plymouth, NC & $13.31(8.58-20.8)$ & $3.51 \pm 0.47$ & $221.3(191.4-258.6)$ & $512.7(407.8-736.4)$ & 4.94 & 5 \\
\hline Stoneville, MS & $5.34(4.97-5.75)$ & $1.43 \pm 0.15$ & $189.9(147.9-252.9)$ & $1490.0(923.2-2990.1)$ & 2.37 & 5 \\
\hline Rosemont, MN & $3.00(2.14-4.00)$ & $3.17 \pm 0.31$ & $157.2(128.8-187.5)$ & $850.6(593.4-1542.1)$ & 5.54 & 5 \\
\hline Loxley, AL & $7.55(5.91-9.62)$ & $1.80 \pm 0.13$ & $153.4(118.6-201.0)$ & $792.6(522.7-1513.3)$ & $11.58^{c}$ & 5 \\
\hline Washington County MS & $5.89(4.45-7.75)$ & $2.13 \pm 0.22$ & $129.9(97.7-169.7)$ & $517.9(359.7-921.2)$ & 7.21 & 5 \\
\hline Washington County, MS (Bt) & $3.46(2.43-4.71)$ & $2.51 \pm 0.27$ & $128.8(83.9-174.8)$ & $416.7(290.0-826.6)$ & $22.0^{c}$ & 5 \\
\hline Fayetteville, AK & $3.04(2.65-3.48)$ & $1.84 \pm 0.19$ & $96.24(59.2-136.4)$ & $480.4(316.3-984.9)$ & 8.22 & 5 \\
\hline Laboratory Colony & $3.44(2.30-5.01)$ & $2.86 \pm 0.36$ & $70.3(49.5-91.6)$ & $197.3(146.6-317.8)$ & 5.46 & 5 \\
\hline
\end{tabular}

\footnotetext{
${ }^{a}$ Concentration of CrylAb that produces $50 \%$ growth inhibition relative to untreated controls. Calculated by nonlinear regression fitted to a probit model.

${ }^{b} \mathrm{ng}$ CryIA $(\mathrm{b}) / \mathrm{cm}^{2}$ of treated artificial diet surface.

${ }^{c}$ Chi-square significant $(P<0.05)$.
} 


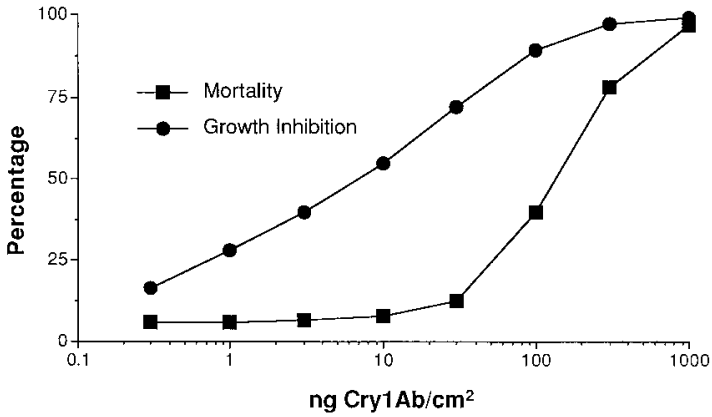

Fig. 1. Comparisons of dose-response curves for mortality and growth inhibition of corn earworm neonate larvae exposed to increasing concentrations of the CrylAb B. thuringiensis toxin. Each point represents the mean response from all 13 populations tested.

$\mathrm{LC}_{50}$ and $\mathrm{EC}_{50}$, respectively. Similar levels of susceptibility were observed in collections that originated from Bt corn and non-Bt hybrids (Washington County, MS).

Sigmoid curves were observed for both mortality and growth inhibition responses (Fig. 1). The convergence of the two curves noted at the upper end of the response distribution is not unexpected given that mortality included both extreme growth inhibition and true mortality. Growth inhibition data (established by weighing individual larvae) were more sensitive than mortality data for detecting the sublethal effects of CrylAb. The differences between $\mathrm{LC}_{50}$ and $\mathrm{EC}_{50}$ values ranged between 18- and 36-fold, indicating that the toxin was having significant effects on corn earworm growth and development at concentrations much lower than those that caused mortality. The implications of such sublethal effects are unknown, but could be important to field exposures and the development of corn earworms on Bt transgenic corn not expressing a high dose. If development is delayed in response to sublethal exposure, mating synchrony between insects developing on Bt corn versus nontransgenic hybrids might be disrupted.

Apart from the increased sensitivity observed in the growth inhibition data, there was no clear advantage in using growth inhibition instead of mortality data. The range of variation in susceptibility was similar between the two response criteria, and because mortality data are easier and faster to collect, this response should be more appropriate for large-scale susceptibility monitoring efforts.

Although variation in susceptibility to CrylAb was observed, the magnitude of the difference was small (i.e., less than fivefold) and similar to other estimates of baseline variability among geographically distinct populations of other insect species. Stone and Sims (1993) found considerable interpopulation variation in B. thuringiensis suceptibility to CrylAc and formulated Dipel among U.S. populations of both corn earworm and cotton budworm (16- and fourfold, respectively). These data were reexamined by Sims et al. (1996), who suggested that interpopulation variation in B. thuringiensis susceptibility may reflect nongenetic variation or sampling error, because the populations tested represented a small sample, taken at one time, of considerably larger multivoltine populations. Similar levels of variability were also observed among European corn borer susceptibility to CrylAb and CrylAc (Marçon et al. 1999) that included populations of different voltine ecotypes and pheromone strains.

The variation in baseline susceptibility to $B$. thuringiensis toxins may reflect differences in vigor among parental populations (Rossiter et al. 1990), attributes that are the product of both genotype and the maternally determined nutritional status of the egg. Variation in susceptibility to $B$. thuringiensis toxins has been reported among repeated bioassays against larvae from single strains of Colorado potato beetle and diamondback moth (Robertson et al. 1995) and European corn borer (Marçon et al. 1999). Intrapopulation variation in response to chemical or microbial insecticides is a common phenomenon when any bioassay is repeated (Robertson et al. 1995), and the extent of both inter-and intrapopulation natural variation in susceptibility to a given pesticide should be investigated before biologically important changes can be identified with any certainty. Ideally, this should be done before the product is used commercially rather than after resistance is already widespread. Because the commercialization of both transgenic cotton and corn preceded the data collection in the current study, it is possible that significant selection may have already occurred. However, based on the limited variation seen in this initial comparison, it appears unlikely that the small differences in response are the result of prior selection and are more likely to have resulted from natural variability in susceptibility among geographically distinct corn earworm populations.

Development of baseline susceptibility data represents the first step toward the development of a monitoring program designed to detect changes in susceptibility that may result from repeated and prolonged exposure to $\mathrm{Bt}$ toxins. These data also may provide information that will allow development of diagnostic bioassays that would be more efficient in detection of resistant populations. However, it should be noted that corn earworm neonates are generally less sensitive to CrylAb than other Lepidopterans such as the European corn borer (Marçon et al. 1999). As a result, designation of diagnostic concentrations equivalent to an $\mathrm{LC}_{99}$ may be difficult to achieve because of the large amounts of purified crystal toxins that would be required for large scale testing of field populations.

\section{Acknowledgments}

The authors acknowledge the contributions of J. VanDuyne (North Carolina State University), Don Parker (Mississippi State University), and T. Horner and G. Dively (University of Maryland) who generously provided their time in collecting $H$. zea for inclusion in this study. A. Anderson (Agripest Crop Consulting) conducted initial rearing of some field populations. M. Shcarf and L. Meinke provided 
critical review of an earlier draft of the manuscript. Funding for this work was provided by Novartis Seeds and Monsanto Company. This is journal series number 12765 of the University of Nebraska Agricultural Experiment Station and contribution number 1030 of the Department of Entomology.

\section{References Cited}

Dennehey, T. J. 1987. Decision-making for managing pest resistance to pesticides, pp. 118-126. In M. G. Ford, D. W. Holloman, B.P.S. Khanbay, and R. M. Sawicki [eds.], Combating resistance to xenobiotics: biological and chemical approaches. Ellis Horwood, Chichester, England.

Finney, D. J. 1971. Probit analysis. Cambridge University Press, Cambridge, UK.

Fischhoff, D. A. 1996. Insect-resistant crop plants, pp. 214227. In G. J. Persley [ed.], Biotechnology and integrated pest management. CAB, Wallingford, UK.

Gould, F. 1998. Sustainability of transgenic insecticidal cultivars: integrating pest genetics and ecology. Annu. Rev. Entomol. 43: 701-726.

Hokkanen, H. M., and J. Wearing [eds]. 1994. OECD workshop on ecological implications of transgenic crop plants containing Bacillus thuringiensis toxin genes, pp. 395-609. In Biocontrol science and technology, vol. 4, no. 4. Carfax, Oxfordshire, UK.

International Life Sciences Institute. 1998. An evaluation of insect resistance management in Bt field corn: a sciencebased framework for risk assessment and risk management. ILSI, Washington, DC.

Keith, D. L., and J. F. Witkowski. 1996. Insects that feed on corn ears. NebGuide Series. G96-1300-A. Institute of Agriculture and Natural Resources, University of Nebrska Cooperative Extension, Lincoln, NE.

LeOra Software. 1987. POLO-PC. A user's guide to probit and logist analysis. LeOra Software, Berkeley, CA.

Marçon, P.C.R.G., L. J. Young, K. L. Steffey, and B. D. Siegfried. 1999. Baseline susceptibility of European corn borer (Lepidoptera: Crambidae) to Bacillus thuringiensis toxins. J. Econ. Entomol. 92: 279-285.
Mason, C. E., M. E. Rice, D. D. Calvin, J. W. Van Duyn, W. B. Showers, W. D. Hutchinson, J. F. Witkowski, R. A. Higgins, D. W. Onstad, and G. P. Dively. 1996. Eur. corn borer ecology and management. North Central Regional Publication 327. Iowa State University, Ames.

Metcalf, R. L., and R. A. Metcalf. 1993. Destructive and useful insects: their habits and control, 5th ed. McGrawHill, New York.

Neunzig, H. H. 1969. The biology of the tobacco budworm and the corn earworm in North Carolina. N.C. Agric. Exp. Stn. Tech. Bull. 196.

Robertson, J. L., H. K. Preisler, S. S. Ng, L. A. Hickle, and W. D. Gelernter. 1995. Natural variation: a complicating factor in bioassays with chemical and microbial pesticides. J. Econ. Entomol. 88: 1-10.

Rossiter, M., W. G. Yendol, and N. R. Dubois. 1990. Resistance to Bacillus thuringiensis in gypsy moth (Lepidoptera: Lymantriidae): genetic and environmental causes. J. Econ. Entomol. 83: 2211-2218.

SAS Institute. 1988. SAS procedures guide, release $6.03 \mathrm{ed}$. SAS Institute, Cary, NC.

Sims, S. R., J. T. Greenplate, T. B. Stone, M. A. Caprio, and F. L. Gould. 1996. Monitoring strategies for early detection of Lepidoptera resistance to Bacillus thuringiensis insecticidal proteins, pp. 229-242. In T. M. Brown [ed.], Molecular genetics and evolution of pesticide resistance. American Chemical Society Symposium Series. ACS, Washington, DC.

Stone, T. B., and S. R. Sims. 1991. Insect rearing and the development of bioengineered crops. In T. E. Anderson and N. C. Leppla [eds.], Advance in insect rearing for research and pest management. Westview, Boulder, CO.

Stone, T. B., and S. R. Sims. 1993. Geographic susceptibility of Heliothis virescens and Helicoverpa zea (Lepidoptera: Noctuidae) to Bacillus thuringiensis. J. Econ. Entomol. 86: 989-994.

Tabashnik, B. E. 1994. Evolution of resistance to Bacillus thuringiensis. Annu. Rev. Entomol. 39: 47-79.

Received for publication 8 September 1999; accepted 10 April 2000 . 